\title{
FLOOD HAZARD ASSESSMENT AND DELIMITATION OF THE LIKELY FLOOD HAZARD ZONES OF THE UPPER PART IN GALLIKOS RIVER BASIN
}

\author{
Tsitroulis I. ${ }^{1}$, Voudouris K. ${ }^{1}$, Vasileiou A. ${ }^{2}$, Mattas C. ${ }^{1}$, Sapountzis M. ${ }^{3}$ and \\ Maris F. ${ }^{2}$ \\ ${ }^{1}$ Aristotle University of Thessaloniki, Department of Geology, 54124, Thessaloniki, Greece, \\ g_tsitroulis@yahoo.gr,kvoudour@geo.auth.gr,cmattas@geo.auth.gr \\ ${ }^{2}$ Democritus University of Thrace, Department of Forestry and Management of the Environment \\ and Natural Resources68200,Orestiada, Greece, apovassi@gmail.com,fmaris@fmenr.duth.gr \\ ${ }^{3}$ Aristotle University of Thessaloniki, Department of Forestry, 54124, Thessaloniki, Greece, \\ sapuntzi@for.auth.gr
}

\begin{abstract}
Floods are one of the most common natural hazards in global range and could threat the human life, health, environment and infrastructure. The aim of this paper is the estimation and the delimitation of the likely flood hazard zones, for different rainfall intensities in the upper part of Gallikos river basin (central Macedonia) according to the European directive 2007/60. For the analysis of the meteorological data and the construction of flood zone maps, HYDROGNOMON, HEC-HMS, HEC-RAS free software packages were used. The thematic maps were constructed with ESRI GIS. The results are depicted in flood inundation maps, delimitating and visualizing the scale of the flood hazard effect in the area. The construction of flood prediction models is a very useful tool towards the direction of the design of an efficient flood management framework.

Keywords: Mapping, Natural hazards, Flood management, Vulnerability maps.

\section{Пєрí̇}

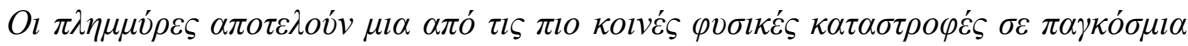

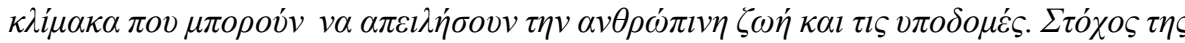

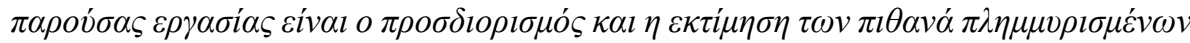

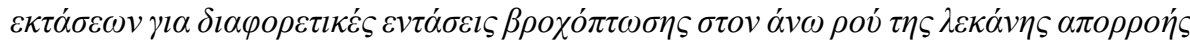

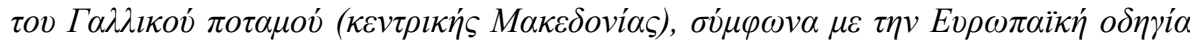

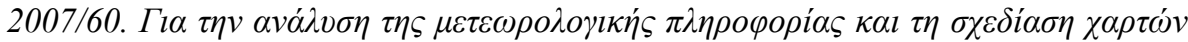

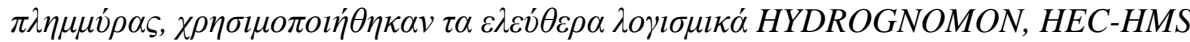

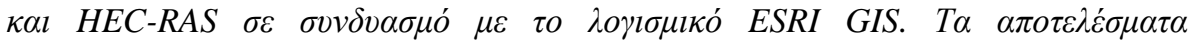

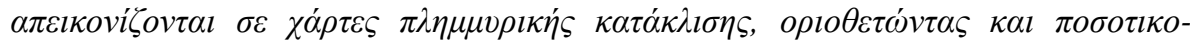

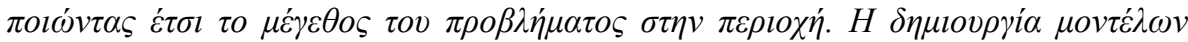

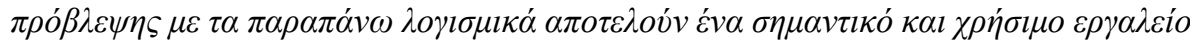

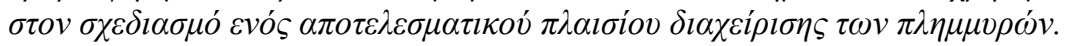

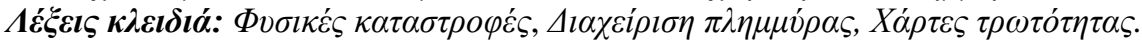




\section{Introduction}

Climate change has contributed to the increase of extreme weather events worldwide. The dominant scientific opinion on climate variability is that it will increase the frequency of heavy rainstorms, causing high devastation risk from floods for many communities (Karl, 2009; Domakinis et al., 2014). According to global range insurance organizations, such as the Munich Re (2002), for the period 1950-2002 floods corresponded to $26 \%$ of the large scale disasters, $8 \%$ of human death rate and $27 \%$ of the economic cost caused by natural disasters. According to Kleinen and Petschel-Held (2007) approximately $20 \%$ of the global population lives in drainage basin areas, which are more likely to be affected by an increase of flood hazard in the future. As a result, based on this climate variability trend, an increase of the natural disaster costs around the globe (Rosenzweig et al., 2007) is expected, which would mostly affect the flood-prone areas.

Therefore, only an effective flood hazard management framework can reduce an upcoming flood hazard increase. The most modern management techniques include hydro-informatic applications, such as flood forecast modeling (Golian et al., 2010), flood hazard, and flood risk mapping in order to achieve an accurate assessment of the flood zones and vulnerable areas (Stefanidis and Stathis, 2013; Kazakis et al., 2015). This paper focuses on the flood hazard assessment and the detection of the flood hazard zones in the upper part of the Gallikos river basin. The meteorological and hydrological data were evaluated with the HYDROGNOMON Software package. The HEC-HMS, HEC-RAS free software packages were also used, whereas the flood plain maps are illustrated in GIS environment.

\section{Study Area}

The upper and largest part of the Gallikos river basin, administratively belongs to Kilkis Prefecture (Northern Greece), with a small downstream part of the watershed belonging to Prefecture of Thessaloniki. The river originates from Kroussia mountain range, flows through Kilkis and Thessaloniki valleys and finally discharges into the Thermaikos Gulf, western wards of Thessaloniki. The entire river basin covers an area of $950 \mathrm{Km}^{2}$. The river length is $65 \mathrm{Km}$ and the annual mean flow is estimated at $39.5 \mathrm{~m}^{3} / \mathrm{s}$ (Poulos et al., 2000). The basin has a pear-like shape with NNE-SSW orientation. In the last fifty years, due to the significant anthropogenic interference, especially during the '70s (FRA report, 2012), the river had seasonal flow only in the downstream part. According to Mattas (2009), during the summer months Gallikos had no flow at the upper part, whilst in some dry years had no flow at all. There is no significant recharge of the river from springs that discharge in the riverbed. Despite the low flow rate of the river, large floods have occurred over the last years, causing disasters in the vulnerable areas. The most recent noteworthy events were recorded during the years 2004, 2014 and 2015.

The study area is delimited by the borders between the Prefectures of Kilkis and Thessaloniki (Fig. 1) and covers an area of $845.95\left(\mathrm{Km}^{2}\right)$. The perimeter is $135.62(\mathrm{Km})$ and the maximum width 25 $(\mathrm{Km})$. The mean altitude and slope are $353(\mathrm{~m})$ and $14.2(\%)$, respectively. The slope is significantly higher at the north mountainous part of the basin. The hydrographic network is very dense and well developed. It follows the dendritic pattern and is characterized by torrential flow. The length of the main branch is approximately $48(\mathrm{Km})$. The riverbed depth is low, which, in combination with the extreme heavy storms, favours the flood phenomena.

The basin belongs to the Circum Rhodope geotectonic zone and Serbo-Macedonian massif (Mercier 1966; Mountrakis 1985). The pre-alpine formations mainly consist of paleozoic gneisses, schists, amphibolites and quartzites (Mercier, 1966). Limestones of Triassic and Jurassic age outcrop at the central-southern part of the basin. The Quaternary deposits comprise lacustrine, terrestrial, fluviatile and fluviatile-torrent sediments, with sands, clays and conglomerates (Meladiotis, 1984). The nonirrigated arable land, along with the agricultural land covered by mixed natural vegetation and pastures, prevail in the area. Circumferentially, and especially at the NNE part, the land is covered 
by mixed forest areas. Artificial surfaces, such as industrial areas, occupy the smallest area in the basin (EEA-Corine CLC, 2000). According to the 2011 census (National Statistical Service of Greece), the population is 40,207. The majority of the inhabitants are employed in the agricultural and the livestock farming, which are the two main occupation sectors at the areas along the Gallikos River. The industrial sector corresponds to small and medium size enterprises near the city of Kilkis, which is the biggest urban center of the basin (Mattas, 2014). The area is characterized as an impervious small roughness basin, due to the relatively impermeable ground surface, the developing husbandry, the lack of significant forested land, the agroforestry practises, and the fact that the agriculture activity involves only annual crops. Such conditions favour the surface runoff.

The main aquifer system is developed in the Quaternary deposits and the groundwater level is near to the ground surface. The depth of the boreholes is relatively small (ranges from 15 to $20 \mathrm{~m}$ ). The boreholes that have been drilled near the river bed, show the highest yield (mean value $90 \mathrm{~m}^{3} / \mathrm{h}$ ). The limestones cover a small area and the aquifers developed in them are of high importance since they cover the drinking demands of many villages in the area. The intensive tectonic activity in the area created a secondary porosity in the pre-alpine formations (paleozoic gneisses prevail in the study area). Due to this porosity low potential aquifers developed in these originally impermeable rocks.

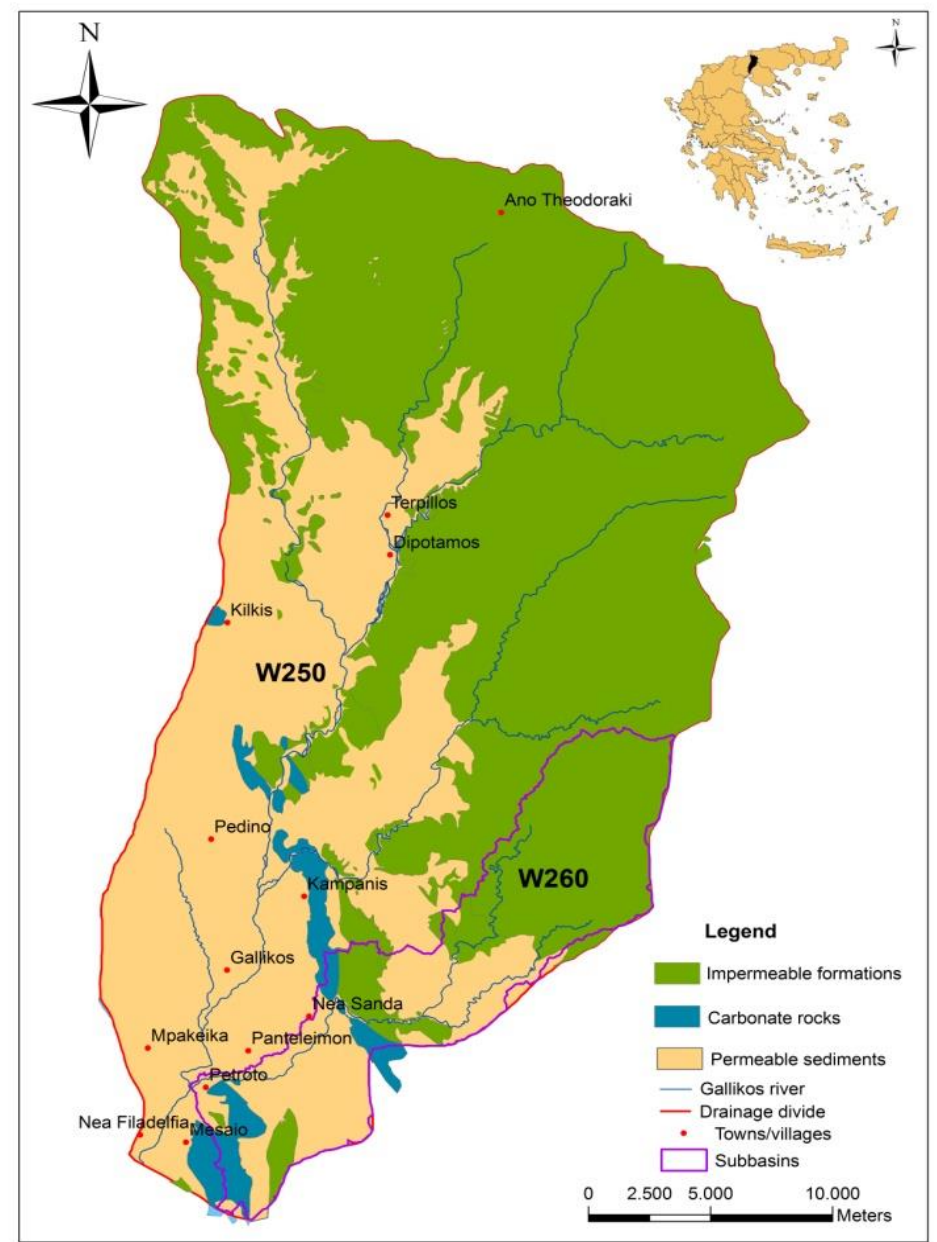

Figure 1 - The study area of Gallikos river basin. 


\section{Materials and methods}

\subsection{Methodology and materials}

The methodology followed in this paper concerns two basic sections, the hydrologic modelling and the hydraulic modelling. The Intensity-Duration-Frequency (IDF) curves were used for the hydrologic modelling, which resulted in the production of three different unit hydrographs. The unit hydrograph that estimates the highest discharge was used for the hydraulic modelling. The result is the flood hazard assessment by means of the flood zones delimitation. The flood hazard of the basin was examined for two different return periods (50 and 100 years). The procedure involves several software products and is described in detail in the following paragraphs.

The boundary of the basin was digitized with ArcGIS 10.2.2, based on 1:50,000 scale topographic maps. The following data were used: (i) a high resolution Digital Elevation Model (DEM) provided by the National Cadastre \& Mapping Agency S.A. (2012), (ii) digital geological maps based on the relative maps of the IGME, and (iii) the Corinne land cover/use maps (EEA-Corine CLC, 2000).

\subsection{Rainfall analysis}

Due to the lack of measurements, regarding rainfall and flood discharge data, the "Design Storm" method was used (VICAIRE, 2003). For the implementation of this method the IDF curves were constructed using the HYDROGNOMON 4.1 software, which is appropriate for the analysis and processing of hydrological data, mainly in the form of time series (Kozanis et al., 2010). The maximum annual rainfall values were used as the required initial hydrologic data for the construction of the IDF curves. The data were derived from the rainfall station Ano Theodoraki (OTME et al., 1985), which is located at the north part of the basin (Fig. 1). The resulted IDF curves are depicted in Fig. 2.

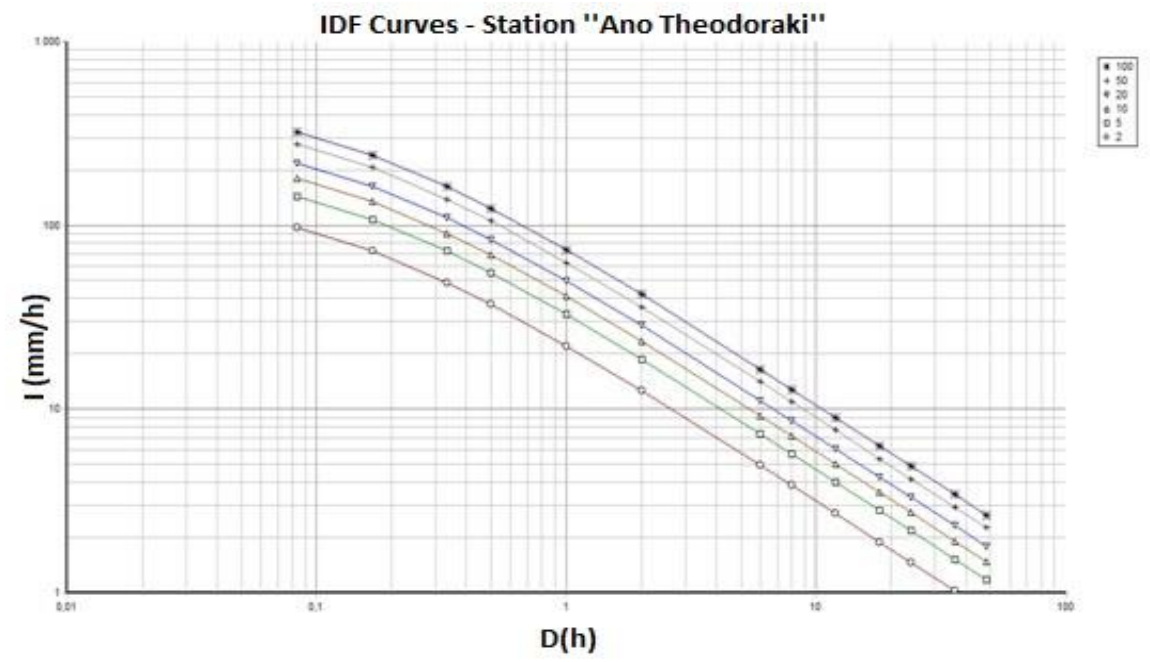

Figure 2 - IDF curves for the station Ano Theodoraki.

The rainfall is characterized by a constant intensity over its duration, which is at least equal to the time of concentration in the "Design Storm" method. The basin's concentration time was estimated at 14.5 hours, using the formula of Giandotti (Voudouris, 2013). The intensity is calculated to be $6.13(\mathrm{~mm} / \mathrm{h})$ for 50 years and $7.14(\mathrm{~mm} / \mathrm{h})$ for 100 years return period. Based on the calculated intensities two corresponding design precipitation hyetographs (Fig. 3) (mm/ $\Delta \mathrm{t}$ ), were drawn, with the use of the Areal Reduction Factor (Koutsoyiannis and Xanthopoulos, 1999), which was calculated to be 0.876, and the Alternate Block Method (Papamihail, 2004). 

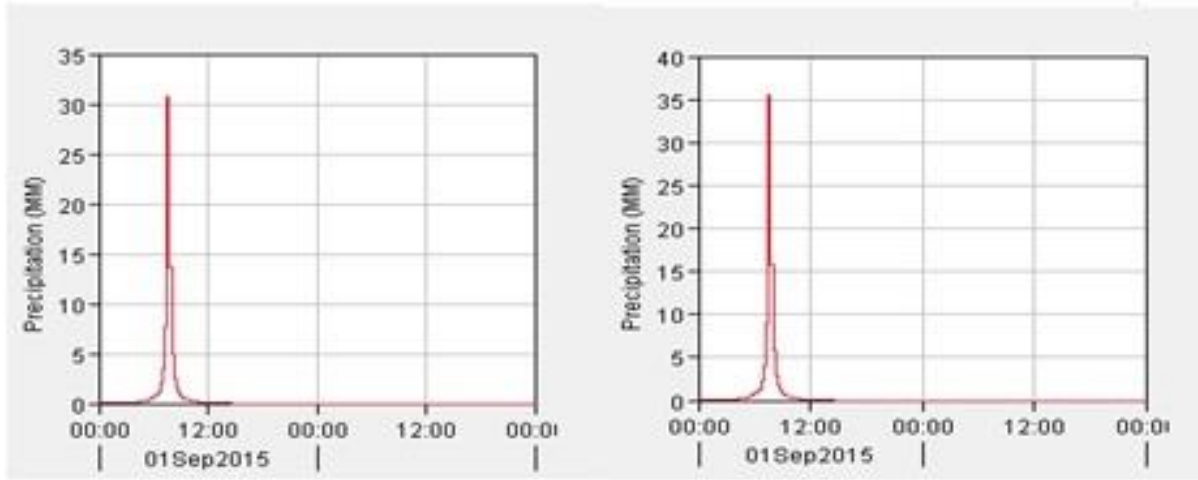

Figure 3 - Design precipitation hyetographs for 50 years return period (left) and 100 years return period (right).

\subsection{Hydrologic modelling}

The rainfall-runoff modelling was realised with the HEC-HMS 3.5 software, which has been developed by the US Army Corps of Engineers (USACE) Hydrologic Engineering Center (HEC). It aims to simulate the precipitation runoff processes of watershed systems and includes different components, such as runoff volume, baseflow, and channel flow (USACE, 2010).

The hydrologic modelling of the basin regards the construction of the unit hydrographs. In order to achieve the latter, several hydrologic multi-analysis pre-processing and main processing operations upon the DEM were required, using the ARC Hydro 2.0 and the geospatial extension HEC-GeoHMS 10.2 in ArcGIS 10.2 environment. The chosen method for the watershed losses is a USDA Natural Resources Conservation Service development, the runoff Curve Number $(\mathrm{CN})$. The $\mathrm{CN}$ is a dimensionless empirical parameter for predicting runoff or infiltration from rainfall excess (USDA, 1986). It ranges from 30 to 100, with large numbers indicating high runoff potential. The separation of the soil groups was achieved by data based on the geological maps of the area. The Corine Land cover classes, integrated with different CN tables (Miliani et al., 2011), were used for the land cover modelling. The CN classifies the AMC (Antecedent Moisture Condition) in three different classes: dry (I), average (II) and moist (III). The soil moisture condition was calculated for AMC II (average conditions) and, as a result, for the sub-basins W250 and W260 (depicted in Fig. 1), the $\mathrm{CN}_{\text {II }}$ is 73.21 and 74.17, respectively.

For the routing it was used the Muskingum - Cunge method (Cunge, 1969) for two reasons. First, the parameter that this method uses can be calculated based on flow and channel characteristics and second, because it makes possible the extensive channel routing in ungaged streams with a reasonable expectation of accuracy (Ponce, 1989). For each return period, the flow was examined using three different synthetic unit hydrograph methods: Clark (Ponce, 1989), Snyder and SCS (Papamihail, 2004). The two hyetographs that were produced in the precedent step with Hydrognomon were used as time-series data. The results are given at Table 1.

Table 1 - Peak discharges from hydrograph methods on return periods 50 and 100 years (all values are in $\mathrm{m}^{3} / \mathbf{s}$ ).

\begin{tabular}{|c|c|c|c|c|c|c|}
\hline $\begin{array}{c}\text { Sub- } \\
\text { basin }\end{array}$ & $\begin{array}{c}\text { Clark } \\
(\mathbf{5 0} \text { years })\end{array}$ & $\begin{array}{c}\text { Clark } \\
(\mathbf{1 0 0} \text { years })\end{array}$ & $\begin{array}{c}\text { Snyder } \\
(\mathbf{5 0} \text { years })\end{array}$ & $\begin{array}{c}\text { Snyder } \\
(\mathbf{1 0 0} \text { years })\end{array}$ & $\begin{array}{c}\text { SCS } \\
(\mathbf{5 0} \text { years })\end{array}$ & $\begin{array}{c}\text { SCS } \\
(\mathbf{1 0 0} \text { years })\end{array}$ \\
\hline W250 & 181.1 & 243.8 & 187 & 251.8 & 459.8 & 619.7 \\
\hline W260 & 59.6 & 79.8 & 50.6 & 67.7 & 127.1 & 170.3 \\
\hline Outlet & 218.9 & 294.1 & 226.8 & 304.8 & 561.6 & 755.3 \\
\hline
\end{tabular}


The time-series from all hydrograph methods extended with null values till the elimination of the discharge. The SCS hydrograph required 48 hours. The extension for Clark and Snyder hydrographs was up to 72 hours. The most unfavourable case scenario is given by the SCS hydrographs (Fig. 4) for both return periods, therefore the hydraulic modelling is conducted with these hydrographs.

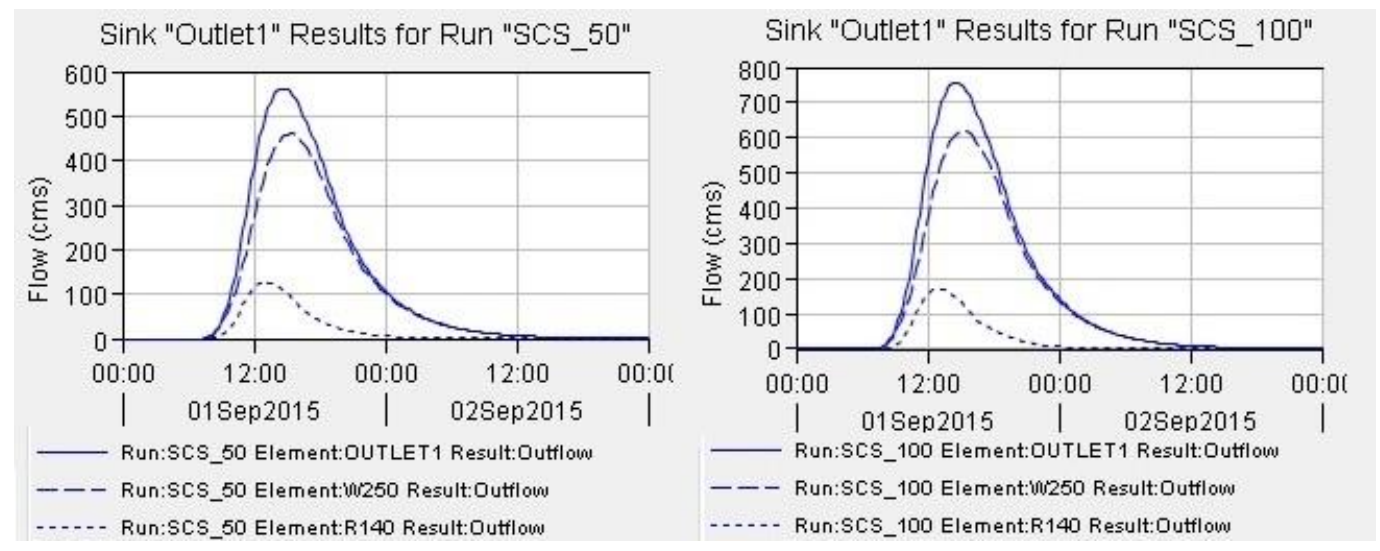

Figure 4 - SCS hydrographs for 50 years return period (left) and 100 years return period (right).

\subsection{Hydraulic modelling}

The hydraulic modelling of the river was realised with the HEC-RAS 4.1 software. HEC-RAS is hydraulic modelling software developed by the US Army Corps of Engineers (USACE) Hydrologic Engineering Center (HEC). It performs one-dimensional steady flow/unsteady flow, sediment transport/mobile bed computations, and water temperature modelling (USACE, 2010b). The hydraulic modelling of the basin results to the hydraulic analysis of the river and the delimitation of the flood zones. The hydraulic analysis in this paper focused between the area of Gallikos and Nea Filadelfia settlements (Fig. 1), because according to the authors experience this area is considered to be one of the most vulnerable for flooding phenomena in the basin for three reasons: (i) this part drains the water from the entire basin as a downstream area, (ii) because the river in this part has very low bed depth (approximately $1.5 \mathrm{~m}$ height), (iii) the technical interventions at this area have a significant impact in flooding phenomena although they were not taken into consideration at the hydraulic modelling.

HEC-RAS model requires data such as topography, Manning's roughness coefficient, flow data, etc. The topographic data were derived from the DEM archive, with the use of geographic river analysis extension HEC-GeoRAS 10.2 in ArcGIS 10.2 environment. The analysis included the construction of several thematic lines such as stream centerlines, flow path lines, bank lines and cross sections (Fig. 5). At the exact points of the different thematic lines a digital topographic map of the area, was used as background.

As it is mentioned before, the basin is characterized as a low roughness area. The estimation of Manning's roughness coefficient was based on the Corine Land cover data and photos of the area. In situ survey for the verification of the Corine data took place. Additional information for open channels roughness values was derived from Chow (1959) and USGS tables (Phillips and Tadayon, 2007). Along a cross section the coefficient varies a lot, depending on the significant land cover differences. The roughness coefficient for the entire river bed ranges between 0.03 and 0.07 , depending on the vegetated segments of the river. The hydraulic modelling conducted for unsteady flow conditions using the SCS hydrographs (of $48 \mathrm{~h}$ duration) that produced in the precedent step with HEC-HMS. The boundary conditions represent the input and output flows from the upstream to the downstream part. 

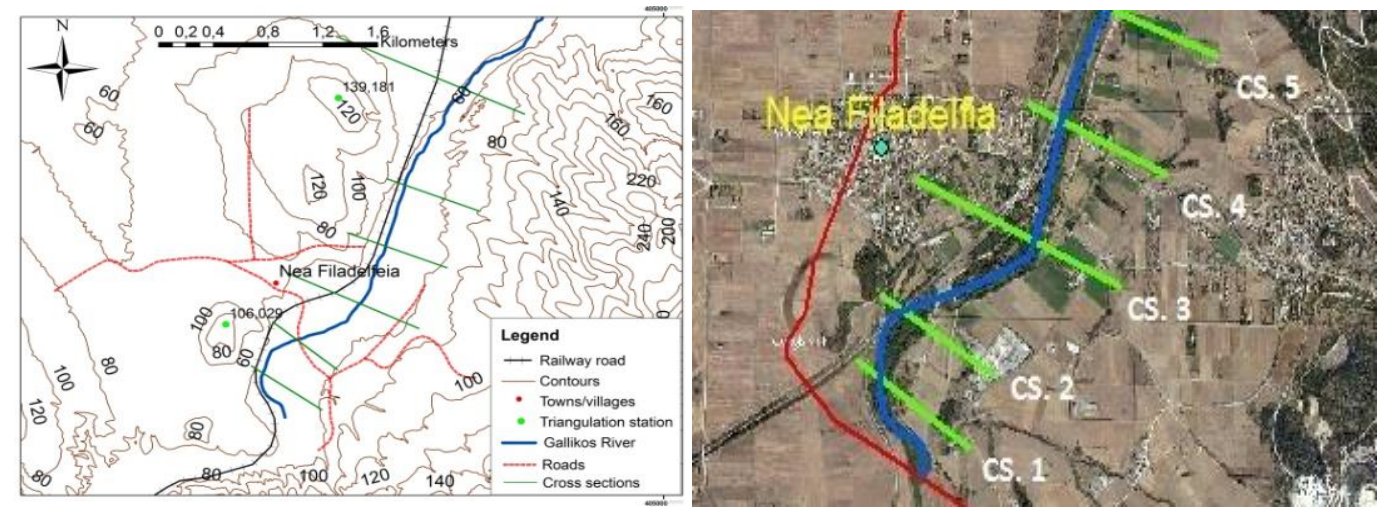

Figure 5 - Thematic lines on topographical (left) and google (right) base map at the outlet area of the basin [the blue line is the river and the green lines are (CS) cross sections].

For the investigated main channel of Gallikos river, the hydrograph of sub-basin W250 was used as input boundary condition and the hydrograph of sub-basin W260 as a lateral inflow (Fig. 1). In the area near to the exit of the basin, the normal depth was used as boundary condition. The mean friction slope of the river, was calculated to be 0.0059 . The hydraulic modelling showed that the Froude number ranges from 0.14 to 0.77 along the river, a value that indicates the subcritical condition of the flow which is consistent with the nature of the river due to the low river bed slope.

\section{Results}

As a result from the hydraulic simulation of the investigated area, the most vulnerable region for the manifestation of flooding phenomena is the Nea Filadelfia village (for both return periods). A large area of agricultural land near the villages Gallikos, Panteleimon and Mpakeika are of high vulnerability too (for return period of 100 years). It is estimated from the analysis that near the settlement (cross section-CS.3, Fig. 6) for return period 100 years the maximum flow is $656\left(\mathrm{~m}^{3} / \mathrm{s}\right)$, the maximum channel depth was estimated at $2.54(\mathrm{~m})$ and top width of the flood at $395(\mathrm{~m})$. For the 50 years return period scenario, the maximum flow is $486\left(\mathrm{~m}^{3} / \mathrm{s}\right)$, the maximum channel depth at $2.09(\mathrm{~m})$ and top width of the flood at $346(\mathrm{~m})$. The two different profiles of the settlement's cross section with the water surface elevation (WSE) and the rating curves are given in Fig. 6.

The visualisation of the flood plain zones was conducted in the ArcGIS 10.2 environment in combination with Google Earth Pro 7.1 map (Google, 2015) using WGS84 coordinate system (Fig. 7). As it is shown, the extent of the floodplains is proportional to the return periods. The 50 years return period floodplain covers an area of $10.42\left(\mathrm{Km}^{2}\right)$ and the 100 years an area of $13.23\left(\mathrm{Km}^{2}\right)$. Both flood case scenarios are verified indirectly (regarding the depth and width of the water in the study area) from the residents testimonies (Vice, 2014), the news reports (http://www.iefimerida.gr/news/182764/laspi-kai-homa-ti-afise-piso-tis-i-kakokairia-ston-gallikopotamo-vinteo-eikones), personal communication and especially from photos of human constructions (Fig. 8), from the historical floods such as the flood in 1966 till the latest in February 2015.

\section{Conclusions-Discussion}

The hydraulic analysis of the Gallikos river basin showed that the settlement Nea Filadelfia is vulnerable at both flood events (50 and 100 years) because a part of the settlement is constructed inside the banks of the river. Also, a large part of agricultural land of the studied area is vulnerable especially on the 100 years return period flood, due to the fact that the area is plain. An additional reason that causes these extensive floods is that the roughness coefficient is higher inside the river than in the area outside of it, due to the heavily vegetated river bed. The construction and 
conservation of embankments along the river on these vulnerable areas is a critical issue. The implementation of agro-forestry techniques will increase the roughness coefficient outside the river and will be effective for the prevention of such phenomena.

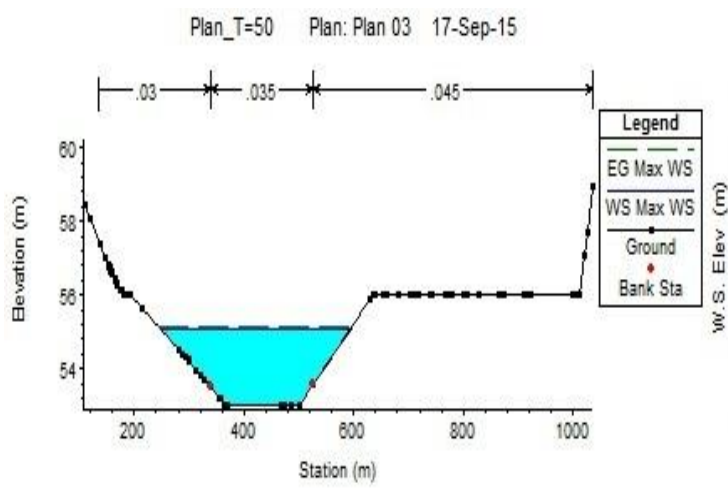

Plan_T=50 Plan: Plan $03 \quad 17-$ Sep-15
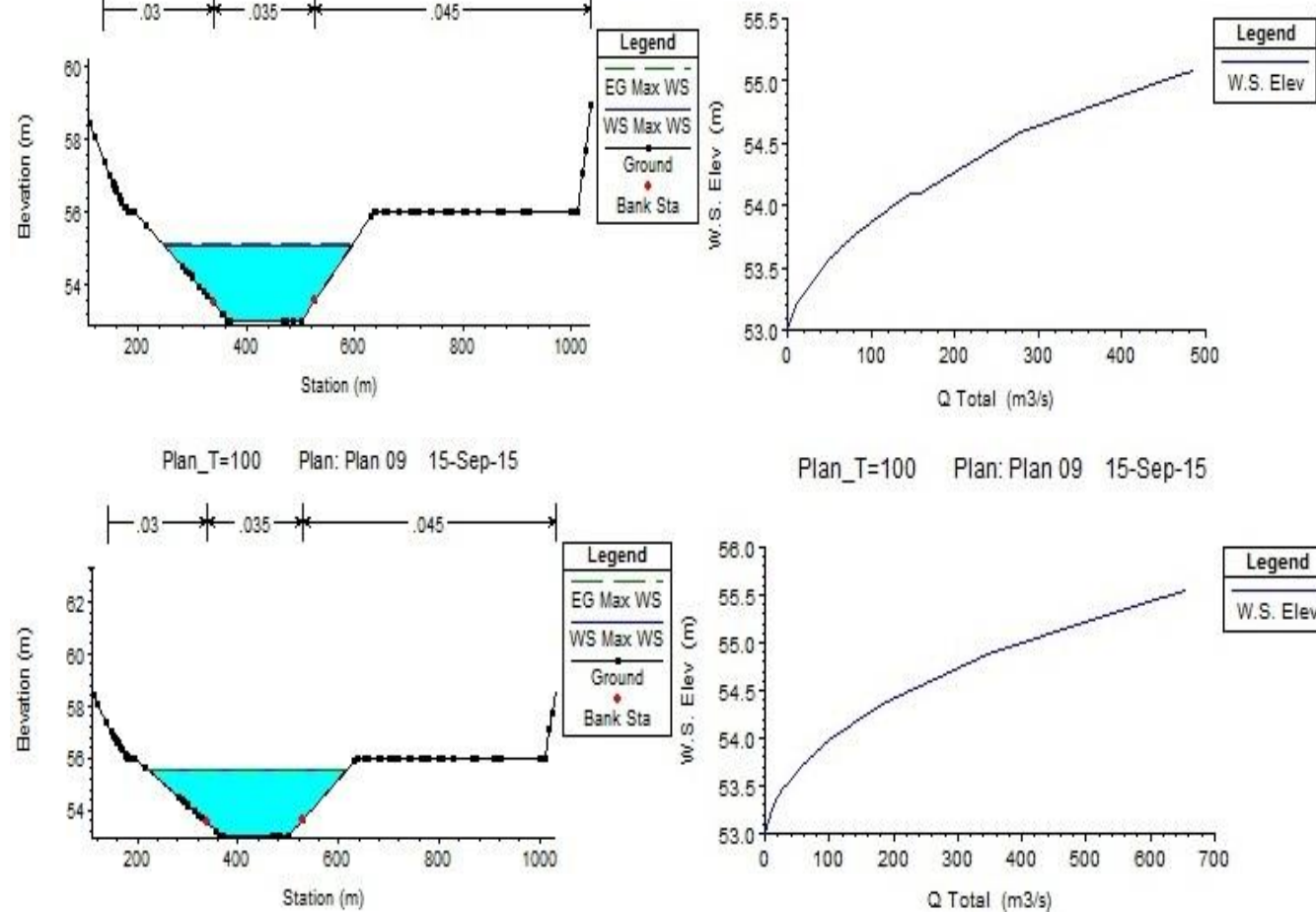

Plan_T=100 Plan:Plan 09 15-Sep-15

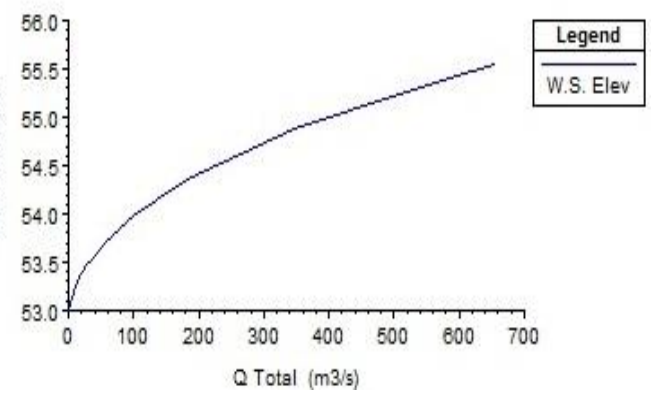

Figure 6 - Cross section (CS.3) at Nea Filadelfia settlement and the rating curves in 50 years return period (above) and $\mathbf{1 0 0}$ years return period (below).
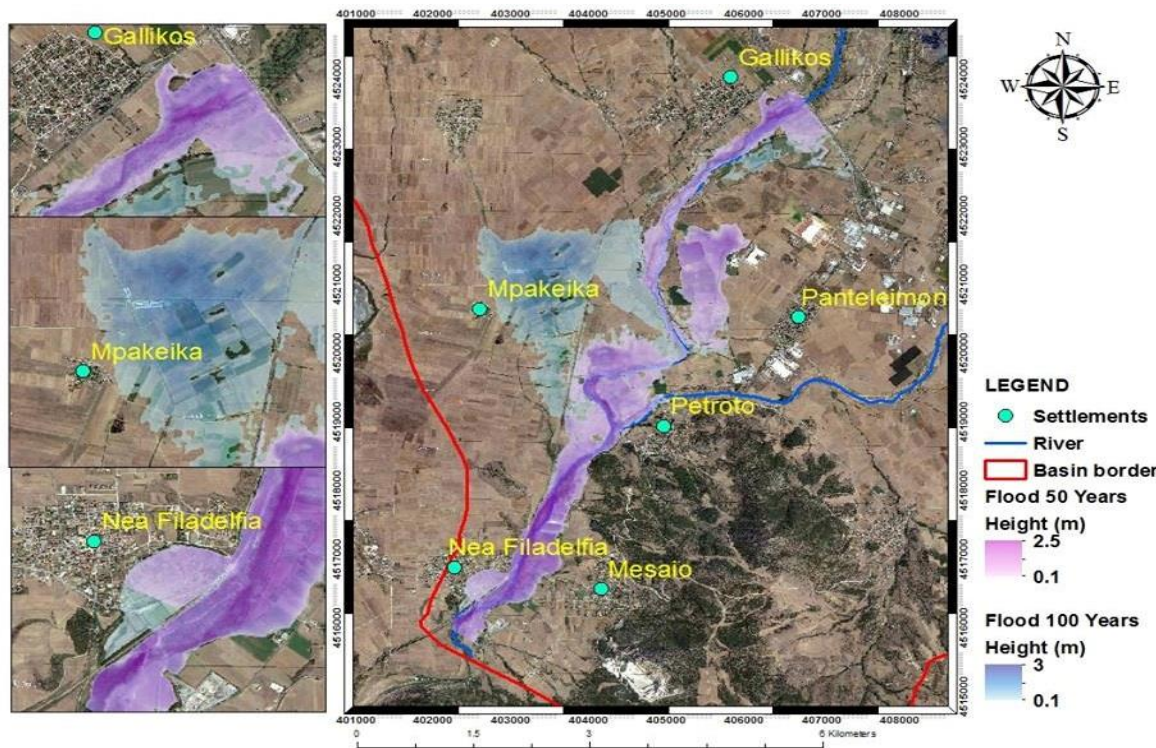

Figure 7 - Floods in Gallikos river basin for return periods (T) 50 years and 100 years. 

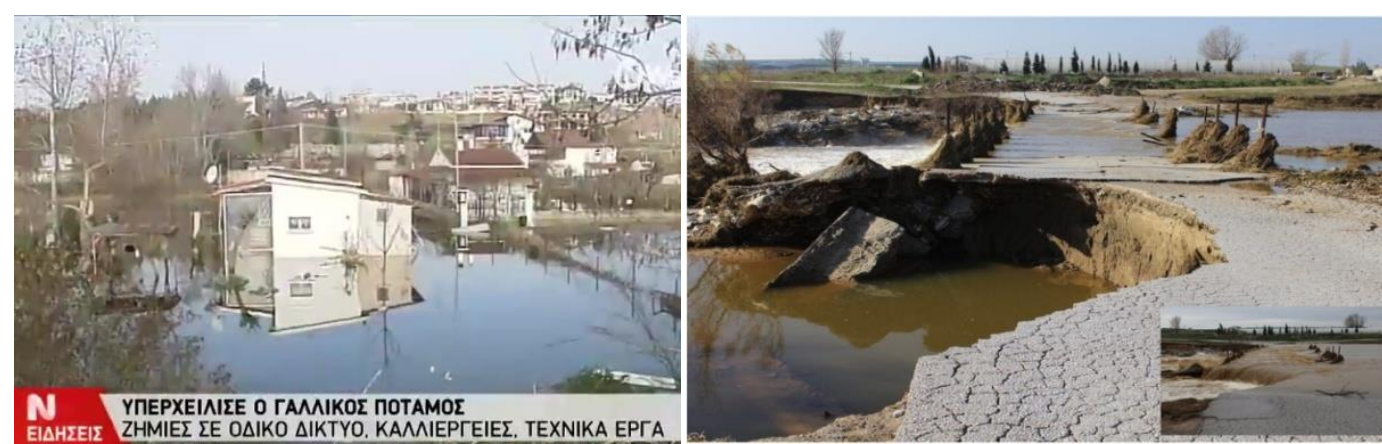

Figure 8 - Indicative damages caused by floods in Gallikos river basin.

\section{Acknowledgements}

This scientific work was carried out in the frame of MSc Thesis of Tsitroulis, I. (2015) at the Laboratory of Engineering Geology and Hydrogeology, Dept. of Geology, Aristotle University of Thessaloniki.

\section{References}

Chow, V.T., 1959. Open-channel Hydraulics, McGraw-Hill book Company, Inc, 109-125.

Cunge, J.A., 1969. On the Subject of a Flood Propagation Computation Method (Muskingum Method), Journal of Hydraulic Research, 7, 2, 205-230.

Domakinis, C., Oikonomdis, D., Voudouris, K. and Astaras, T., 2014. Using geographic information systems (GIS) and remote sensing to map flood extent and to assess flood hazard in Erythropotamos river basin (Evros, Greece), Proc. of $10^{\text {th }}$ International Congress of the Hellenic Geographical Society, Thessaloniki.

EEA-Corine CLC, 2000. European Environment Agency. Corine Land Cover 2000 seamless vector data. Available online at: http://www.eea.europa.eu/data-and-maps/data/corine-land-cover2000-clc2000-seamless-vector-database-5.

FRA report, 2012. Implementation of the European directive 2007/60/EC, Preliminary assessment of the flood hazard, Athens, December 2012, $80 \mathrm{pp}$.

Golian, S., Saghafian, B. and Maknoon, R., 2010. Derivation of Probabilistic Thresholds of Spatially Distributed Rainfall for Flood Forecasting, Water Resour Manage, doi: 10.1007/s11269-0109619-7.

Google, 2015. Google Earth Pro 7.1 maps. Available online at: http://www.google.gr/intl/el/earth/download/gep/agree.html.

Karl, T.R., Melillo, J.M. and Peterson, T.C., eds., 2009. Global climate change impacts in the United States, New York: Cambridge University Press.

Kazakis, N., Kougias, I. and Patsialis, T., 2015. Assessment of flood hazard areas at a regional scale using an index-based approach and Analytical Hierarchy Process: Application in RhodopeEvros region, Greece, Science of the Total Environment, 538, 555-563.

Kleinen, T. and Petschel-Held, G., 2007. Integrated assessment of changes in flooding probabilities due to climate change, Climatic Change, 81, 283-312.

Koutsoyiannis, D. and Xanthopoulos, Th., 1999. Engineering Hydrology, Edition 3, National Technical University of Athens, Athens, 153-154 (in Greek).

Kozanis, S., Christofides, A., Mamassis, N., Efstratiadis, A. and Koutsoyiannis, D., 2010. Hydrognomon - open source software for the analysis of hydrological data, European 
Geosciences Union General Assembly 2010, Geophysical Research Abstracts, Vol. 12, Vienna, 12419, European Geosciences Union.

Mattas, C., 2009. Hydrogeological research in Gallikos river basin, PhD Thesis. Dept. of Geology, Aristotle University, Thessaloniki (in Greek).

Mattas, C., Voudouris, K. and Panagopoulos, A., 2014. Integrated groundwater resources management using the DPSIR approach in a GIS environment: A case study from the Gallikos River basin, North Greece, Water, 6, 1043-1068, doi: 10.3390/w6041043.

Meladiotis, I., 1984. Geological research of the eastern part of Thessaloniki-Yanitson valleys and especially in the area between Axios and Gallikos rivers where are developing exploitable aquifers, PhD Thesis. School of Civil Engineering. Thessaloniki, AUTh (in Greek).

Mercier, J., 1966. Stude geologigue des zones internes des Hellenides en Macedoine Centrale (Greece), Ann. Geol. des Pays Hellenoques, 20, 1-596 (in French).

Mountrakis, D., 1985. Geology of Greece, University Studio Press, Thessaloniki.

Munich, R., 2002. Topics, an annual review of natural catastrophes, Munich Reinsurance Company Publications, Munich.

National Cadastre \& Mapping Agency S.A., 2012. (in Greek).

National Statistical Service of Greece, 2011. Census 2011. Registered Population-Population Distribution.http://www.statistics.gr/portal/page/portal/ESYE/PAGEthemes?p_param=A16 03\&r_param=SAN21\&y_param=2011_00\&mytabs=0.

OTME Ltd, Konstantinidis, D., METER Ltd., 1985. Final study of flood control - drainage project and dam of Artzan - Amatovou, Ministry of Environment, Land planning and Public projects, Athens (in Greek).

Papamichail, D., 2004. Applied Hydrology of Surface Water, Giaxoudi Publications, Thessaloniki, 192 pp. (in Greek).

Phillips, J. and Tadayon, S., 2007. Selection of Manning's Roughness Coefficient for Natural and Constructed Vegetated and Non-Vegetated Channels, and Vegetation Maintenance Plan Guidelines for Vegetated Channels in Central Arizona, U.S. Geological Survey, Reston, Virginia.

Ponce, V.M., 1989. Engineering Hydrology, Principles and Practices, Prentice Hall, 291-297 and 311-313.

Poulos, S.E., Chronis, G.T., Collins, M.B. and Lykousis, V., 2000. Thermaikos Gulf Coastal System, NW Aegean Sea: an overview of water sediment fluxes in relation to air-land-ocean interactions and human activities, Journal of Marine Systems, 25, 47-76.

Rosenzweig, C., Casassa, G., Karoly, D.J., Imeson, A., Liu, C., Menzel, A., Rawlins, S., Root, T.L., Seguin, B. and Tryjanowski, P., 2007. Assessment of observed changes and responses in natural and managed systems, Climate Change, 2007, Impacts, Adaptation and Vulnerability. Contribution of Working Group II to the Fourth Assessment Report of the Intergovernmental 
Panel on Climate Change, Parry, M.L., Canziani, O.F., Palutikof, J.P., van der Linden, P.J. and Hanson, C.E., eds., Cambridge University Press, UK, 79-131.

Stefanidis, S. and Stathis, D., 2013. Assessment of flood hazard based on natural and anthropogenic factors using analytic hierarchy process (AHP), Natural Hazards, 68(2), 569-585, doi: 10.1007/s11069-013-0639-5.

USACE, 2010. U.S. Army Corps of Engineers, Hydrologic Engineering Center, HEC-HMS. Available online at: http://www.hec.usace.army.mil/software/hec-hms/.

USACE, 2010b. U.S. Army Corps of Engineers, Hydrologic Engineering Center, HEC-RAS. Available online at: http://www.hec.usace.army.mil/software/hec-ras/.

USDA, 1986. United States Department of Agriculture. Urban Hydrology for Small Watersheds, Technical Release 55 (TR-55) (Second Edition), Natural Resources, Conservation Service, Conservation Engineering Division.

VICAIRE, 2003. Virtual campus in hydrology and water resources. Module 1B, Engineering hydrology, Chapter 2, Design storm.

Vice, 2014. VICE Media LLC. Gallikos: The "Dead" river woke and drowned people. December 12, Athens, 2014. Available online at: http://www.vice.com/gr/read/gallikos-to-nekropotami-ksypnise-kai-epnikse-anthropous.

Voudouris, K., 2013. Engineering Hydrogeology, Tziolas Publ., Thessaloniki, 128-130 (in Greek). 